\title{
Studies on the Production of the Montecristo Banana Grown on the Adjuntas Region of Puerto Rico
}

\author{
F. Sanchez Nieva, G. Colom Covas, I. Hernández, R. Guadalupe, \\ C. Bueso de Viñas, and A. Torres ${ }^{1}$
}

\section{INTRODUCTION}

In a previous publication (2) 2 the authors reported the results of a study conducted on the Southern Coast of Puerto Rico to determine the effect of the time of planting and flowering on fruit development, production patterns, fruit quality, and ripening characteristics of the Montecristo bananas. This paper describes the results of similar studies conducted in the Mountainous Region of Puerto Rico where bananas are commercially grown.

\section{EXPERIMENTAL PROCEDURES}

Monthly plantings of 100 plants each were established under full sunlight at the Adjuntas Substation at an elevation of approximately 1,800 feet above sea level. The first plot was planted in December 1963. Successive plots were established monthly at about 30-day intervals until November 1964.

Planting material of the cultivar known in Puerto Rico as Montecristo Grande was obtained from trees growing in the experimental farm to shade coffee. The seeds (pseudo-rhizomes) were chosen to be of similar size and weight, and were planted at a distance of 10 feet $\times 10$ feet. The corms were peeled and dipped in a 2.5-percent solution of Aldrin to control the borer, Cosmopolites sordidus, G. The planting holes were treated also with the same solution, and the plots were sprayed 180 days after planting.

Fertilizer formula 12-6-10 was applied according to the following schedule: 1 pound 60 days after planting and 1 pound every 60 days until shooting, the last application given at the time of shooting.

To control the Sigatoka leaf spot disease (Cercospora musae) the plants were sprayed with Orchard Spray Oil every 15 days at the rate of 3 to 4 liters per cuerda. ${ }^{3}$ The plantations were weeded as needed. No shoots were allowed to grow until shooting.

1 Technical Director, Associate Horticulturist, Assistant Chemical Engineer, Assistant Horticulturist, Assistant Food Technologist, respectively, Food Technology Laboratory, Agricultural Experiment Station, Mayagüez Campus, University of Puerto Rico, Río Piedras, P.R., and Horticulturist in Charge of Fortuna Substation, formerly Associate Horticulturist in Limani Substation, Agricultural Experiment Station, Mayagüez Campus, University of Puerto Rico, Ponce, P.R.

2 Numbers in parentheses refer to Literature Cited, pp. 327-8.

s One cuerda $=0.9712$ acre . 
Dates of shooting were recorded. Bunches were harvested at predetermined ages measured from the time of shooting. The bunches were transported to the Laboratory wrapped in padded cotton mats to avoid bruising. The bunches were weighed with the stem attached, but with both the male bud and its stem cut-off closed to the last hand. The hands and fingers were counted. Fingers from the second hand were sampled for chemical analyses and to determine the weights of pulp and peel. Pulp:peel ratios were calculated from average weights of pulp and peel.

To study the ripening characteristics, the bunches were left overnight at room temperature and placed in the ripening room the next morning. The temperature of the ripening room was adjusted to $68^{\circ} \mathrm{F}$., with a relative humidity of 95 to 100 percent. After staying 1 day in the ripening rooms, ethylene was applied at the rate of 1 cubic foot per 1,000 cubic feet of room space. A second ethylene dosage was applied 7 to 8 hours later. Following the ethylene application, the room was ventilated with an exhaust fan through a bunk door for 15 minutes every 24 hours. After turning, the temperature was lowered to $66^{\circ} \mathrm{F}$. until the fruit reached a peel color of 4 to 5 , according to the color-chart published by the Fruit Dispatch Co. (5). The average weights of fingers from all hands were recorded. Fingers from the second hand were removed for chemical analyses. All analyses were run on the pulp and the results expressed in terms of the fresh-pulp weight.

\section{RESULTS AND DISCUSSION}

EFFECT OF THE TIME OF PLANTING ON FLOWERING PATTERNS

The flowering characteristics of the 12 plots are given in table 1 . The interval from planting to the first shooting ranged from a minimum of 296 to a maximum of 372 days. The interval from planting to the time at which 50 percent of the plants had shot ranged from 371 to 448 days. Values for the standard deviation for the interval from planting to shooting ranged from 21 to 28 days in seven plots, from 32 to 38 days in three plots and from 43 to 48 days in two plots.

The length of the interval from planting to the time the first shooting was visible does not follow any definite trend which can be correlated with the time of planting. With the exception of the first three plots, in which the interval from planting to the first shooting decreased consecutively from 330 to 296 days, alternate short and long periods were observed in the remaining plots (table 1). This variation in the interval from planting to shooting resulted in some plots blooming within the same month. Plots Nos. 4 and 5, planted in March and April, respectively, 35 days apart, started to bloom in February within a period of 8 days. Similarly, Plots Nos. 7 and 8, planted respectively, in June and July, started to bloom in the following 
June within a period of 12 days. Plots Nos. 9 and 10, planted respectively in August and September, started to bloom on the same day of the following August.

The duration of the period of flowering for each plot is given in table 1 . The span of the period of flowering ranged from a minimum of 107 days to a maximum of 200 days. The duration of the period of flowering varied with the time of planting, increasing from a minimum value of 107 days for the

TABLE 1.-Planting and flowering dates and characteristics of the period of flowering for the 12 plots

\begin{tabular}{|c|c|c|c|c|c|c|}
\hline \multirow[b]{2}{*}{ Plot No. } & \multirow[b]{2}{*}{ Planting date } & \multirow[b]{2}{*}{ Period of flowering } & \multicolumn{3}{|c|}{$\begin{array}{l}\text { Interval from planting to } \\
\text { flowering }\end{array}$} & \multirow[b]{2}{*}{$\begin{array}{l}\text { Duration of } \\
\text { fowering }\end{array}$} \\
\hline & & & Range & Mean & $\begin{array}{c}\text { Stand- } \\
\text { ard } \\
\text { devia- } \\
\text { tion }\end{array}$ & \\
\hline & 1963 & 1964 & Days & Days & Days & Days \\
\hline 1 & Dec. 5 & Oct. 30-Feb. 15 & $330-437$ & 376 & 23 & 107 \\
\hline 2 & Jan. 7 & Nov. 18-Mar. 24 & $315-441$ & 375 & 22 & 126 \\
\hline 3 & Feb. 9 & Dec. 2-May 14 & $296-459$ & 371 & 38 & 163 \\
\hline 4 & Mar. 6 & $\begin{array}{l}1965 \stackrel{1965}{195} \\
\text { Feb. 1-Aug. } 13\end{array}$ & $332-525$ & 427 & 48 & 193 \\
\hline 5 & April 10 & Feb. 8-Aug. 27 & $304-504$ & 403 & 43 & 200 \\
\hline 6 & May 7 & Apr. 21-Sept. 24 & $349-505$ & 426 & 32 & 156 \\
\hline 7 & June 10 & June 9-Nov. 18 & $364-526$ & 423 & 27 & 162 \\
\hline 8 & July 7 & $\begin{array}{c}\text { June 21-Nov. } 18 \\
1966\end{array}$ & $349-499$ & 417 & 28 & 150 \\
\hline 9 & Aug. 6 & Aug. 13-Jan. 14 & $372-526$ & 448 & 37 & 154 \\
\hline 10 & Sept. 9 & Aug. 13-Jan. 7 & $338-485$ & 400 & 27 & 147 \\
\hline 11 & Oct. 7 & Sept. 24-Jan. 21 & $352-471$ & 403 & 21 & 119 \\
\hline 12 & Nov. 6 & Oct. 1-Jan. 21 & $329-441$ & 378 & 24 & 112 \\
\hline
\end{tabular}

plot planted in April 1964 and decreasing steadily in consecutive plots to reach a value of 112 days for the plot planted in November 1964.

This relationship between the length of the period of flowering and the time of planting is shown by the curve in figure 1, in which the length in days of the period of flowering has been plotted against the month in which the plot was planted.

The variations observed in the length of the period of flowering which are related to the time of planting suggest that such variations are related to the prevailing weather conditions. In figure 2 the minimum and maximum temperatures and rainfall data for the Adjuntas Substation is given for each month from planting to harvesting. The time at which shooting was first observed in each of the 12 plots is indicated above the minimum 
temperature curve. It should be noted that Plots Nos. 4 and 5 with a long period of flowering of 193 and 200 days, respectively, started to bloom on February at the time when the lowest minimum temperature for the whole period from December 1963 to April 1964 was recorded. Coinciding with the low temperatures, rainfall was very low with the total for the month being less than 1 inch. It should also be observed that the shape of the minimum temperature curve for the period of flowering of all plots follows in opposite direction the shape of the curve in figure 1.

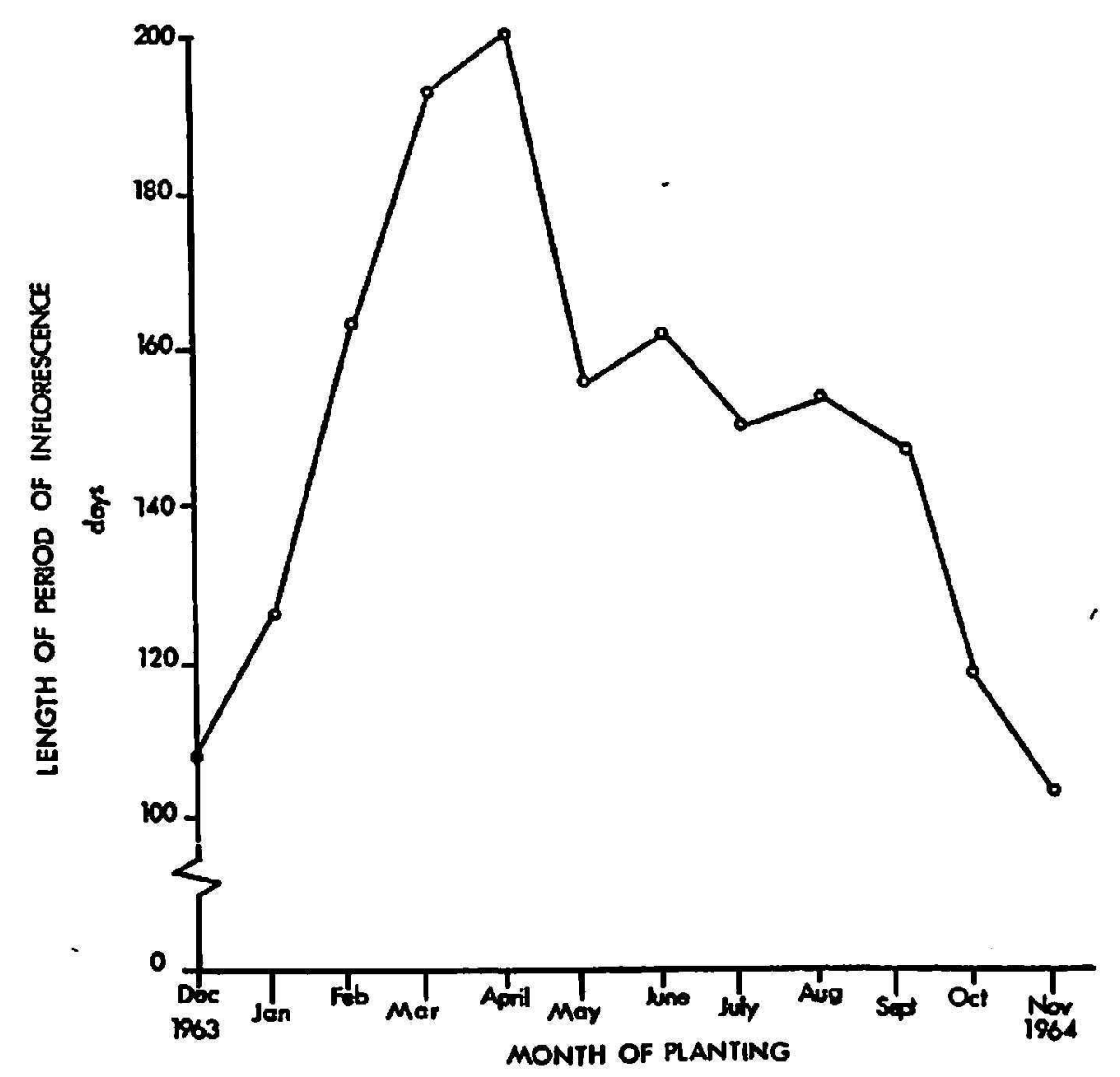

Fra. 1.-Variation in the length of the period of flowering with the time of planting.

The length of the period of flowering affects the production pattern by spreading the period of fruit production. The distribution of plants flowering within this period have also a direct effect on the production patterns since the shape of the frequency distribution curve in terms of the percentage of plants blooming within a given time may vary from a normal distribution to a skew type distribution displaced either toward the beginning or the end of the flowering period, several plots will be blooming at the same time and the flowering period will be extended over a whole year.

The percentage distribution of plants flowering at 10-day intervals for each of the 12 plots are shown in figures $3,4,5$, and 6 . In these figures the 
individual curves are displaced from each other by the corresponding interval in days between the first shooting of consecutive plots.

The flowering characteristics of the 12 plots do not follow any definite pattern. About half of the plots have a skew type distribution with the highest percentage of plants flowering near the beginning or the end of the flowering period. The other half of the plots have a similar to normal distribution with the highest percent of plants flowering near the middle of the
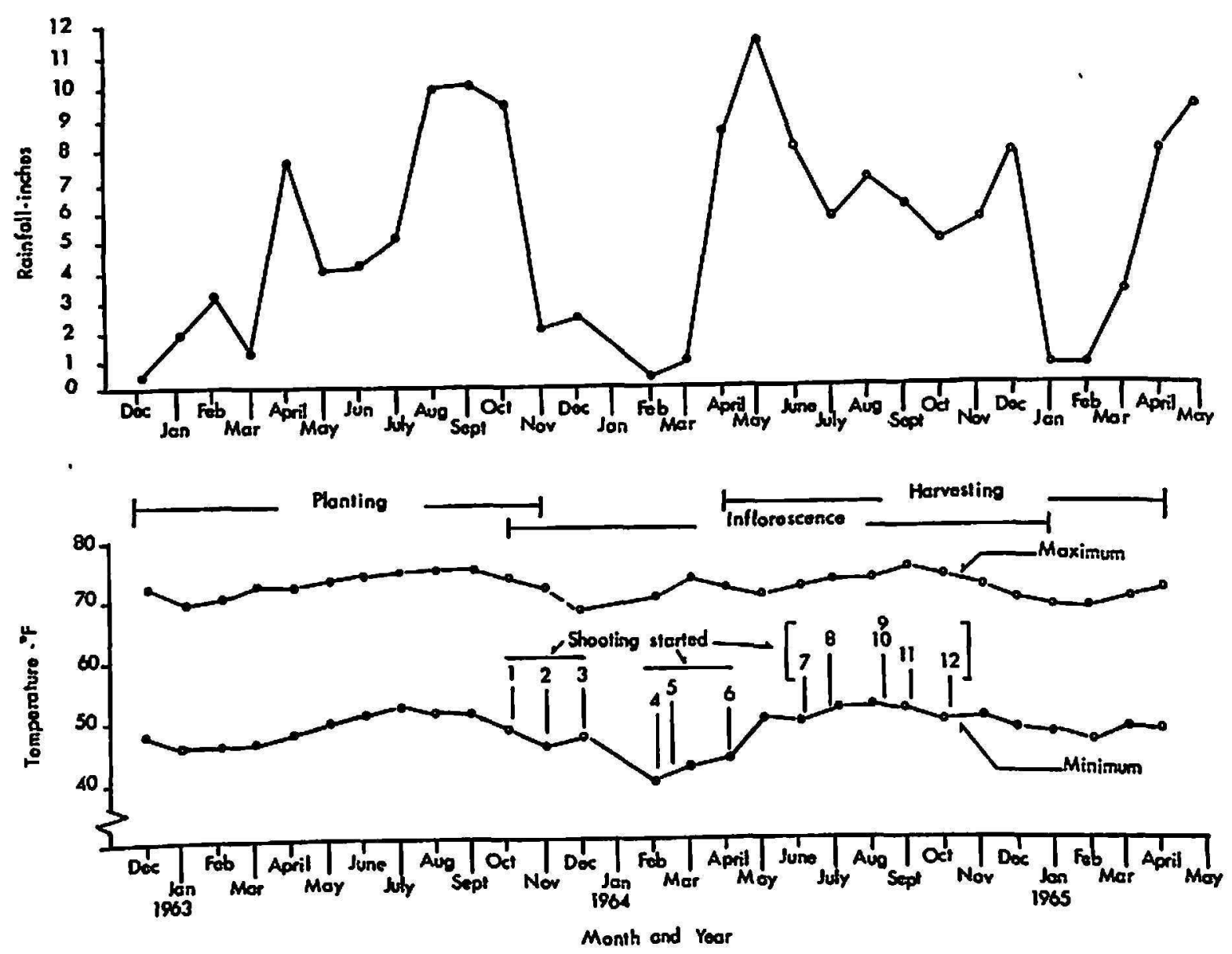

Fic. 2.-Rainfall and temperature data for the period from planting to harvesting.

flowering period. The flowering pattern for all plots is erratic, with alternate periods of low and high percentage of plants flowering. Of particular interest are the curves for Plots Nos. 3, 4, and 5, which show that these plots with a very long flowering period kept blooming fairly uniformly throughout this period without showing any definite maximum peaks like the others.

This study was aimed to determine how the ripening characteristics of the Montecristo bananas grown on the Mountainous Region of Puerto Rico varied with the time of the year in which they were produced, and therefore no replicated plots were established. Consequently, no general conclusions can be drawn about the general behavior of the bananas grown in this area, 


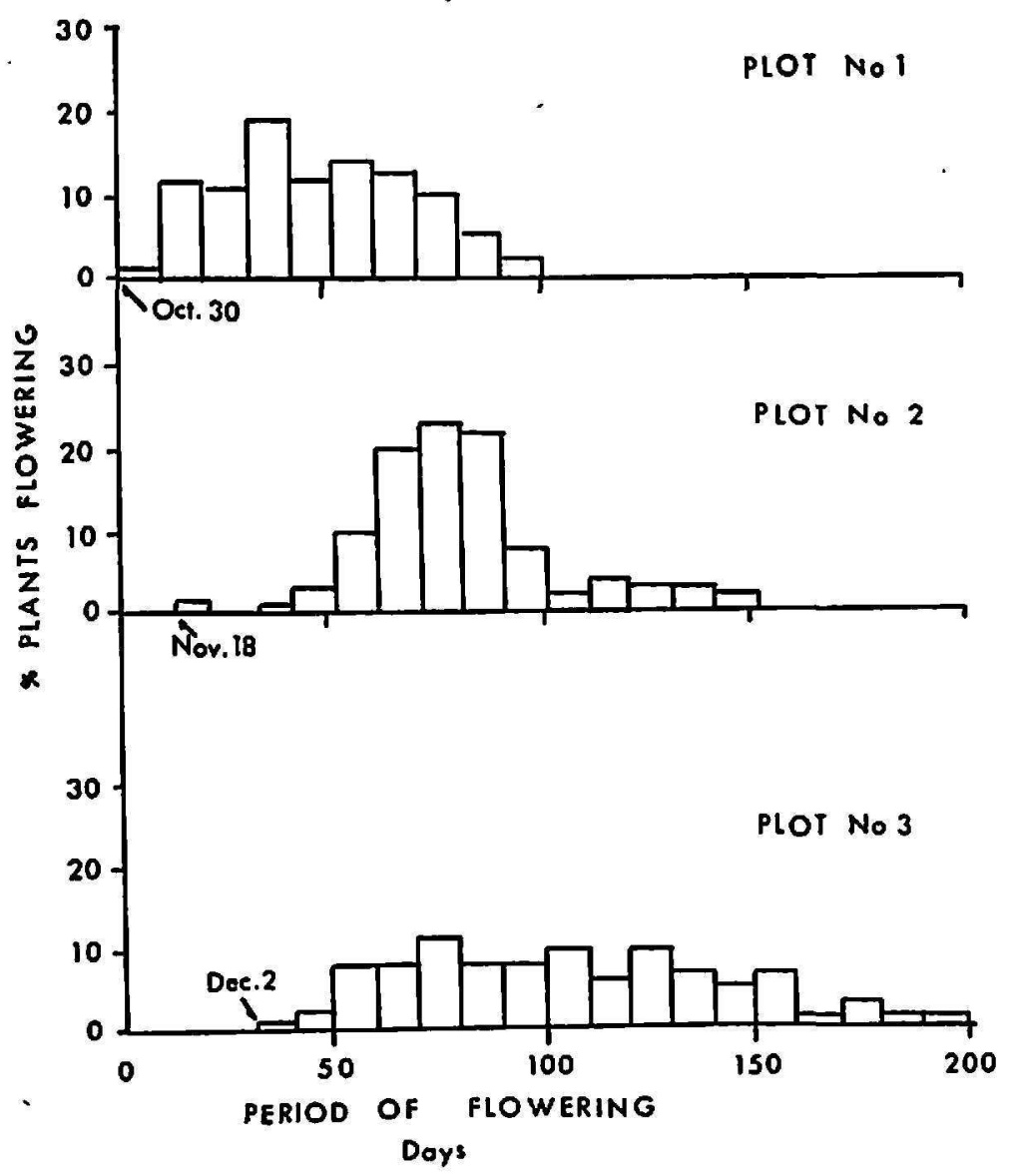

Fra. 3.-Frequency distribution of plants flowering in plots Nos. 1, 2, and 3.

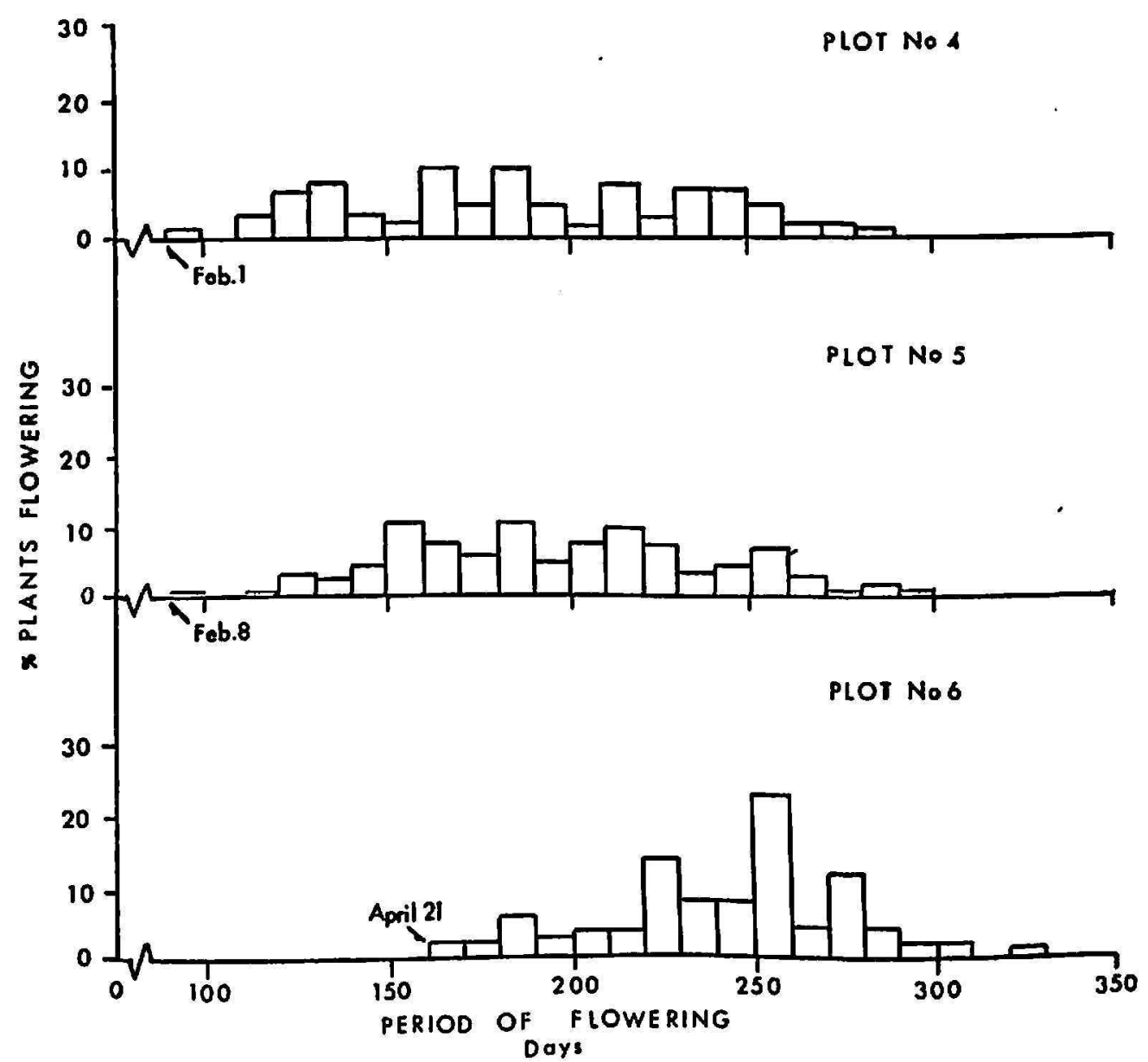

FrG. 4.-Frequency distribution of plants flowering in plots Nos. 4, 5, and 6. 


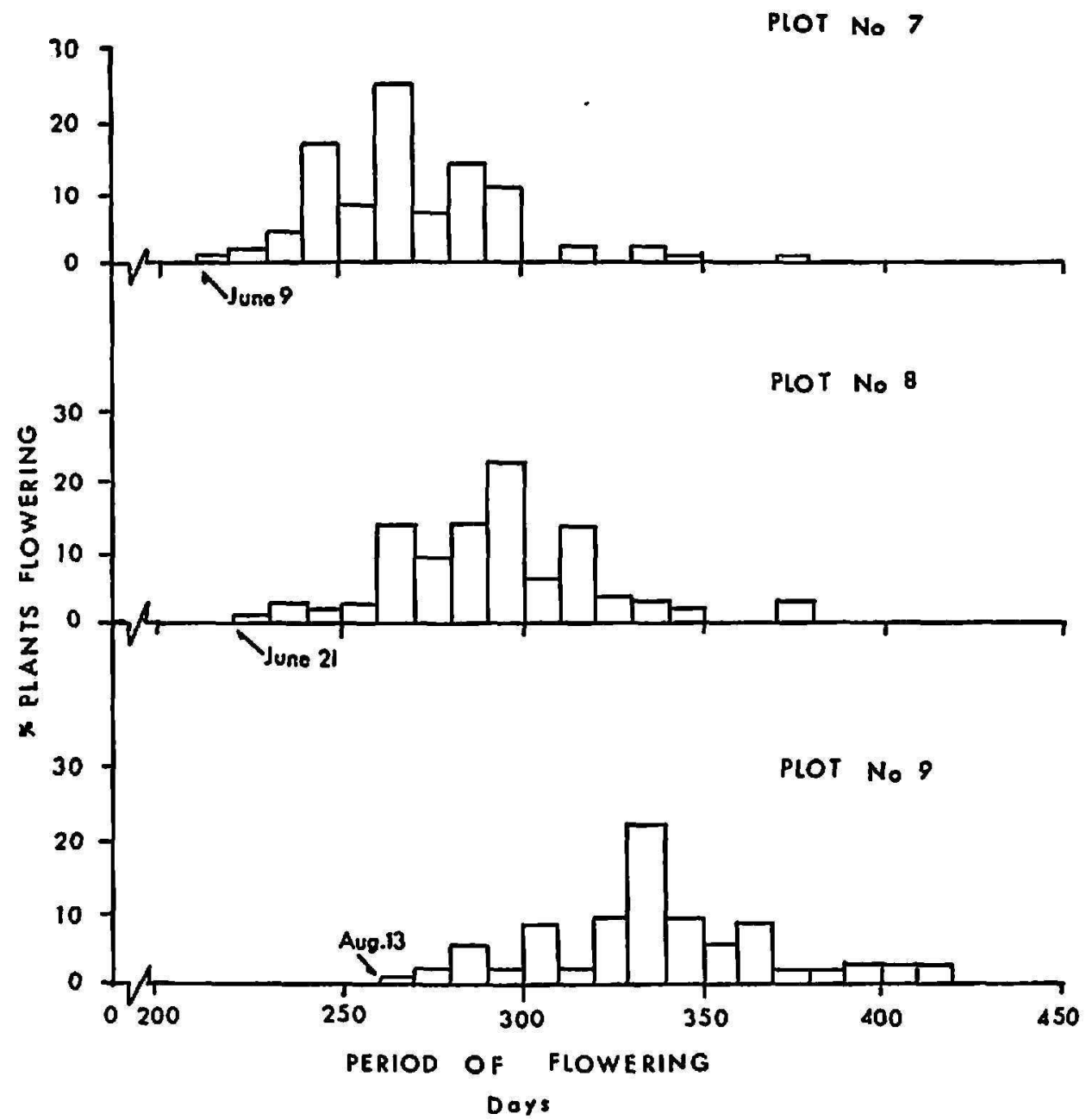

FIG. 5.-Frequency distribution of plants flowering in plots Nos. 7, 8, and 9.

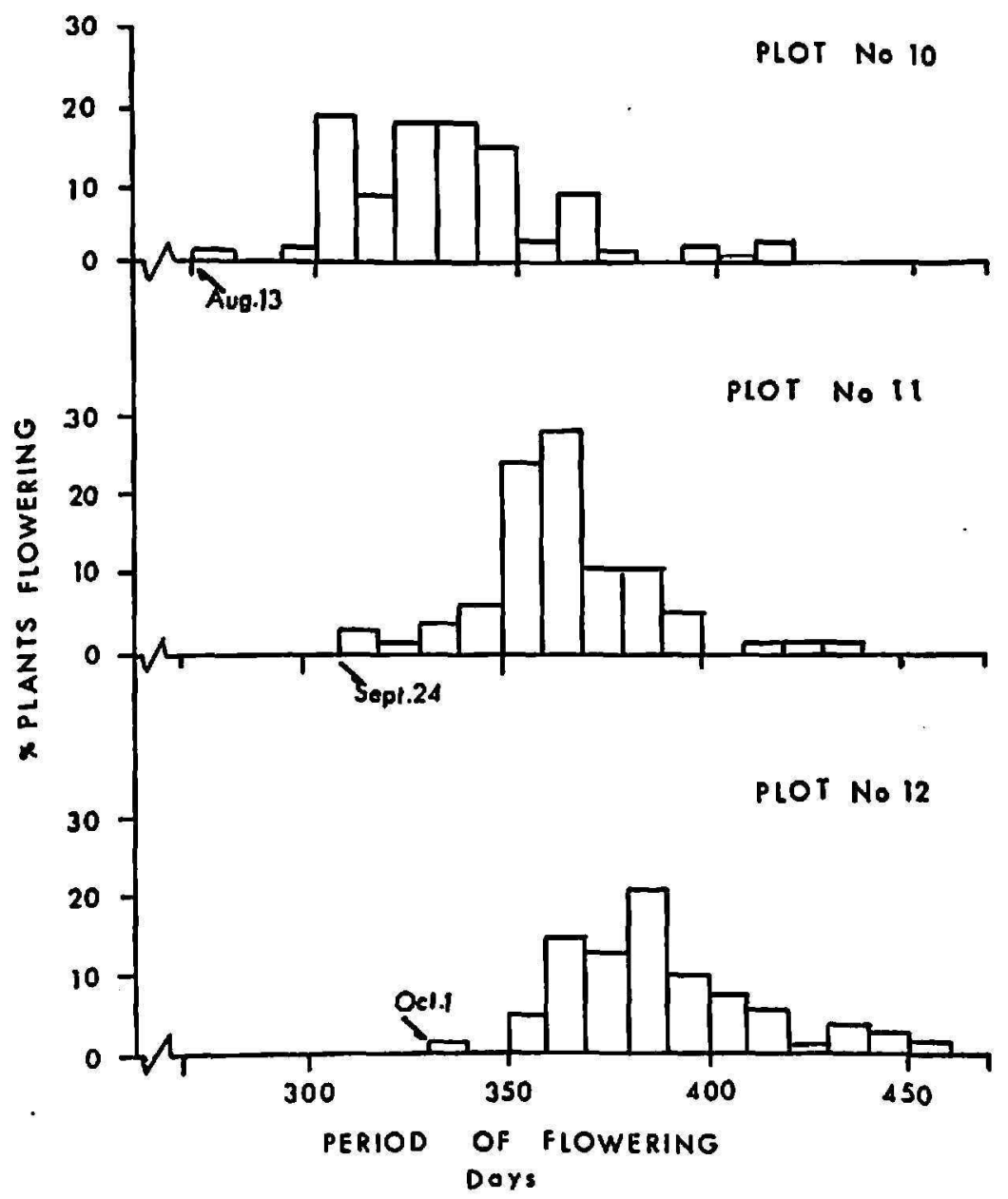

Fra. 6.-Frequency distribution of plants flowering in plots Nos. 10, 11, and 12 . 
which will be affected by prevailing weather conditions. The data obtained from this work on the effect of the time of planting on the flowering patterns give some indications of the expected behavior of plant crops produced under weather conditions similar to those that prevailed during the experiment.

Of particular interest is the flowering pattern of the 12 plots combined which will determine the fruit production pattern for the whole period. The flowering distribution for all 12 plots combined is shown in figure 7.

In this curve, two definite periods of low and high percentage of plants flowering are observed, with the highest percentage of plants flowering during the months of June to November. The displacement of the flowering

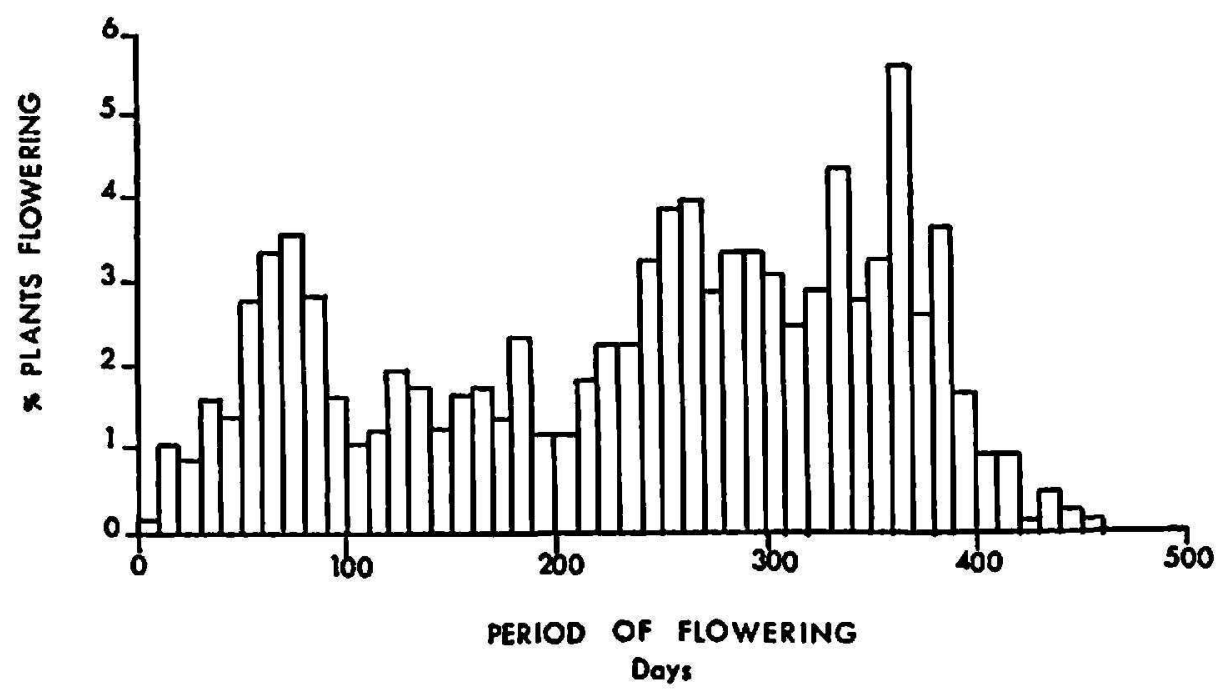

Fra. 7.-Percentage distribution of plants flowering in all 12 plots throughout the period of study.

peak to the later part of the flowering period is mainly due to the long flowering span of Plots Nos. 3, 4, and 5.

FFFECT OF THE TIME OF SHOOTING ON THE DEVHLOPMENT OF THE BUNCH AND ON PRODUCTION PATTERNS

Because of the longer flowering periods exhibited by all plots, several plots will be blooming at the same time, and consequently the fruit produced at any given time will come from several plots. Therefore, it is more appropriate to study the development of the fruit, production patterns, fruit quality, and yields, by grouping the plants into common periods of flowering. Furthermore, since the weather conditions determine the course of development of the bunch, the time of planting has no other effect on the fruit than to determine the time at which fruit set will occur.

Cold weather reduces the development of the banana bunch (2). Under normal conditions of vegetative growth and climate, fruit may be harvested 
for the export market 90 days after shooting. Under unfavorable conditions the interval from shooting to harvesting may be much longer. According to Champion (3), West Africa following a dry spell the fruit must be harvested from 115 to 120 days after shooting. In the Canary Islands and in Australia the period from shooting to harvesting may range from 120 to 180 days during periods of cold weather. On the Southern Coast of Puerto Rico, Sánchez Nieva, et al. (2) found that the Montecristo banana could be harvested at a "three-quarter full" stage of development from 100 to 110 days after shooting. The development of the bunch was found to vary with the time of flowering.

To study the development of the fruit on the Southern Coast of Puerto Rico, Sánchez Nieva et al. (2) used two main criteria: The change in the pulp: peel ratios, and a classification of the fruit according to the angularity of the fingers. These same criteria are used in this study to determine how the time of flowering affects the development of the bunch.

Wardlaw (4) studied the development of the Gros Michel banana and found that the change in pulp: peel ratio is linear during development of the bunch. Sánchez et al. (2) found this relation to hold true for the Montecristo bananas grown on the Southern Coast of Puerto Rico. To find whether the change in the pulp:peel ratio is also linear during periods of slow development as found in the Adjuntas Region, two approaches were followed: A fruit was cut from the second hand of selected bunches of known age at several time intervals during development. In this way fruit from the same bunch was available for this determination reducing the effect of variation which may come by harvesting fruits from different bunches. The second approach consisted of harvesting bunches at different intervals after shooting, selecting only bunches produced from plants flowering within a definite time interval, sampling fruit from the second hand to measure the pulp:peel ratios.

The variation of the pulp:peel ratio with age in fruit harvested from the same bunch is shown in figure 8. Data from 37 fruits harvested from 10 bunches have been plotted. Statistical analysis of the data showed that the pulp: peel ratio changes linearly with age, with the regression coefficient for the straight line being significant to a 1-percent probability level. In figure 9, the pulp: peel ratios of fruit from the second hand of bunches harvested from plants blooming within a month have been plotted against the age in days measured from shooting. During the 4 months of flowering studied, March, June, August, and December, the pulp: peel ratio changed linearly with age. It should be noted, however, that the slope of the curves are different, indicating different rates of development during the period studied.

To determine the effect of the time of flowering on the development of the bunches, a large number of bunches were harvested throughout the year 


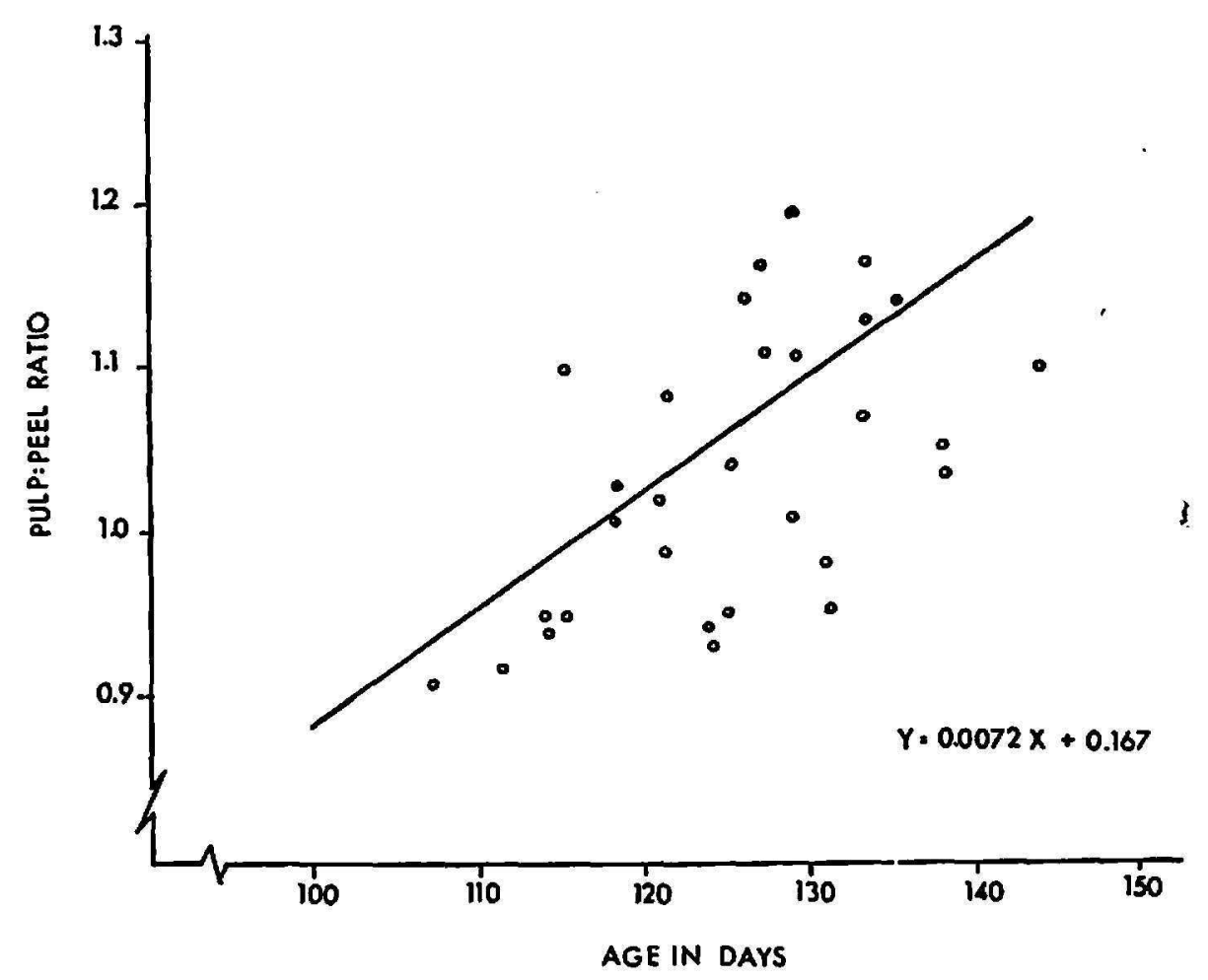

F1G. 8.-Variation in the pulp: peel ratio during development of the fruit.

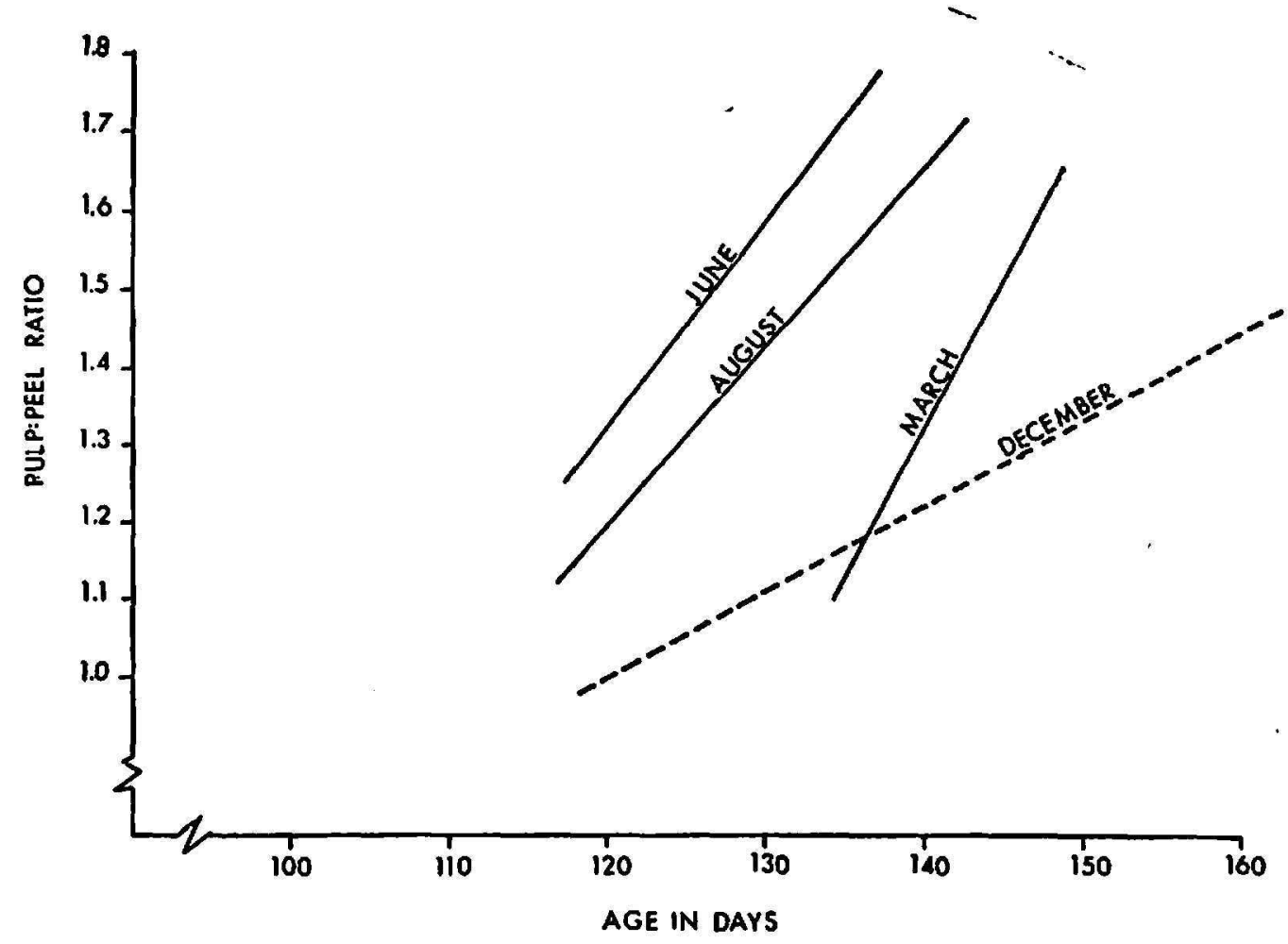

Fig. 9. - Variation of pulp:peel ratios with age in bananas produced by plants flowering during December, March, June, and August. 
and the pulp:peel ratio measured from fruit taken from the second hand. The bunches were grouped according to the range of values for the pulp:peel ratios, as shown in table 2. The average age for each group was determined for each month of flowering. By visual inspection, the bananas were classified by commercial grades (5) based on the appearance of the fruit from the

TABLE 2.-Age in days of banana bunches harvested from plants blooming within a calendar month and having the pulp:peel ratio indicated

\begin{tabular}{l|c|c|c|c|c|c|c|c|c}
\hline \multirow{2}{*}{$\begin{array}{c}\text { Month of } \\
\text { inflorescence }\end{array}$} & \multicolumn{7}{|c|}{ Age in days for the pulp: peel ratio indicated } \\
\cline { 2 - 8 } & $1.00-1.09$ & $1.10-1.19$ & $1.20-1.29$ & $1.30-1.39$ & $1.40-1.49$ & $1.50-1.59$ & $1.60-1.69$ & $1.70-1.79$ & $1.80-1.89$ \\
\hline 1964 & & & & & & & & & \\
$\begin{array}{l}\text { November } \\
\text { December }\end{array}$ & 131 & 142 & 139 & 160 & - & - & 175 & - & - \\
$\quad 1965$ & 142 & 131 & 147 & 152 & 162 & 164 & 172 & - & - \\
January & 117 & 131 & 141 & 148 & 157 & - & - & - & - \\
February & - & 114 & 125 & - & - & - & - & 124 & 167 \\
March & - & 138 & - & 139 & 148 & 147 & 149 & 183 & 163 \\
April & - & - & - & 122 & 139 & 131 & 144 & 149 & 142 \\
May & - & - & - & 123 & 123 & 132 & 130 & - & - \\
June & - & 114 & 117 & 119 & 124 & 128 & 137 & 136 & - \\
July & 90 & 116 & 112 & 116 & 124 & 129 & 129 & 138 & - \\
August & - & 117 & 121 & 123 & 122 & 139 & 131 & 145 & 145 \\
September & - & 131 & 126 & 131 & 132 & 135 & 131 & - & - \\
October & 122 & 126 & 128 & 130 & 146 & 172 & 172 & - & - \\
November & 126 & 143 & 147 & 152 & 156 & 154 & 173 & - & - \\
December & 109 & 145 & 151 & 154 & 187 & 182 & 158 & 144 & - \\
\hline
\end{tabular}

standpoint of its angularity and plumpness. The relationship of pulp:peel ratio to grade is shown on the following tabulation:

Pulp:peel ratio Grade
$1.10-1.29$

"three-quarters"
$1.30-1.49$

"light threequarters"
$1.50-1.80$

"full threequarters"

This classification is intended only to indicate the approximate stage of development of the fruit having pulp: peel ratios within the ranges indicated. The appearance of the fruit varied greatly within each group and fruit with a high pulp:peel ratio of 1.80 apparently never attained the "full" stage.

The values in table 2 have been plotted against the months of flowering in figure 10. All curves show the same trend, indicating that the rate of development of the bunch was affected by the time of the year in which shooting occurred. The effect of shooting on the development of the fruit is best seen by following set $B$ of curves in figure 10 . To reach a stage of develop- 
ment ranging from "light three-quarters" to "full three-quarters", the fruit coming from plants blooming in November had to be harvested from 160 to 166 days after shooting. The age for harvesting at this stage of development

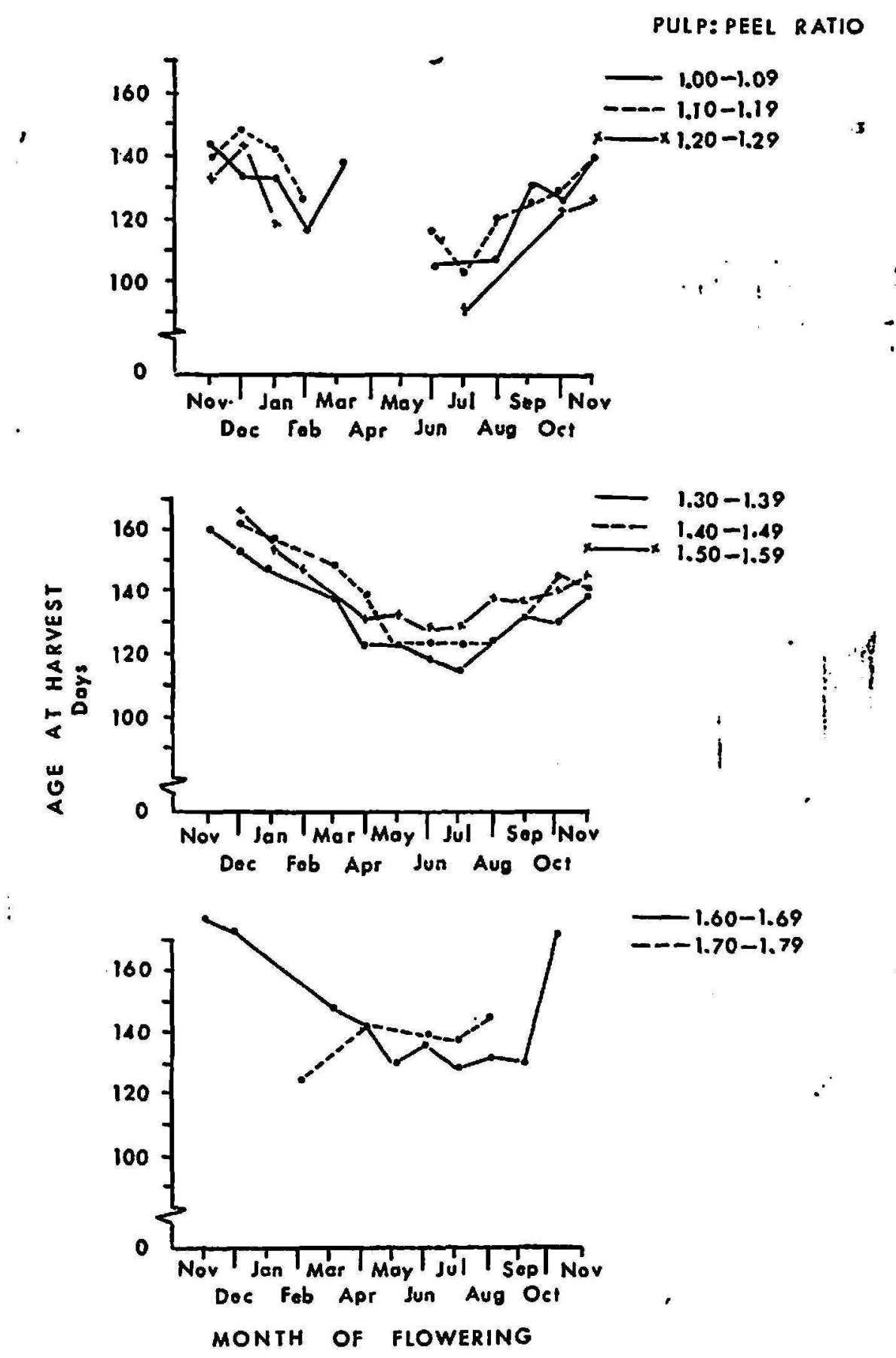

Fro. 10.-Variation in age with the month of flowering for bunches with pulp ratio ranging from 1.00 to 1.79 .

decreased steadily from November on reaching a minimum value of 115 to 128 days from April to August, increasing steadily again through November.

These data suggest that under conditions similar to those that prevailed during this experiment, in the Adjuntas Region fruit has to be harvested at 
different ages throughout the year to maintain quality within a given grade. The long time necessary for the fruit to develop to a "full three-quarters" stage makes it impracticable to harvest the fruit at this stage.

When monthly plots are established, the production pattern will be determined mainly by the pattern of flowering and by the effect of the time of flowering on the development of the bunch, which will determine the age at which the bunches should be harvested for any given grade. The flowering pattern of all 12 plots combined indicated (fig. 7) that the highest percentage of plants bloomed between June and November. The age range for harvesting bunches from plants blooming within this period was found to be 119 to 140 days. As a result of these two effects the period of maximum production will be expected to come from October to February.

In this experiment from a total of 1,200 plants, 795 bunches were harvested, corresponding to 66.3 percent of the total. For several reasons beyond our control, the number of bunches harvested from plants flowering within a calendar month varied throughout the year. Therefore, the distribution by month of the harvest does not indicate the true production pattern of the plantation. However, when the percentage of bunches harvested per month in terms of the total is calculated, the highest percentage of bunches were harvested from October to March, coinciding the period of maximum production with that expected from the combined effect of the flowering pattern and the age at harvesting. In the following tabulation the distribution of bunches by month of harvest is shown:

$\begin{array}{lc}\text { Month hartested } & \text { Percentage harpested } \\ \text { April 1965 } & 3.27 \\ \text { May } & 8.43 \\ \text { June } & 5.28 \\ \text { July } & - \\ \text { August } & 5.79 \\ \text { September } & 8.80 \\ \text { October } & 6.67 \\ \text { November } & 9.43 \\ \text { December } & 11.19 \\ \text { January 1966 } & 11.32 \\ \text { February } & 10.44 \\ \text { March } & 6.67 \\ \text { April } & 8.43 \\ \text { May } & 3.27 \\ \text { June } & 1.00\end{array}$

EFFECT OF THE TIME OF FLOWERING ON YIFLDS

The characteristics of the fruit produced grouped by month of flowering are given in table 3 . The variations in the weight of the bunches, the weight of the fingers, and the number of fruits per bunch with the time of flowering, 
are shown by the curves in figure 11 . The weight of the bunch ranged from 48.50 to 58.11 pounds. Curve $\mathrm{A}$ of figure 11 shows that the average weight of the bunches varied in a cyclic way during the year, and although there is a slight trend for the average weights to decrease from the flowering of November 1964 to the flowering of November 1965, the weights remained fairly constant during the period studied.

The average weight of the fingers ranged from 141 to $213 \mathrm{~g}$. The weight of the fingers increased from the flowering of November 1964 reaching a

TABLE 3.-Characteristics of the fruil produced by plants flowering within a calendar month

\begin{tabular}{|c|c|c|c|c|c|c|}
\hline Month of inflorescence & $\begin{array}{c}\text { Age at } \\
\text { harvesting }\end{array}$ & $\begin{array}{c}\text { Average } \\
\text { weight of } \\
\text { bunch }\end{array}$ & $\begin{array}{c}\text { Average } \\
\text { weight of } \\
\text { fingers }\end{array}$ & Pulp:peel & $\begin{array}{l}\text { Hands per } \\
\text { bunch }\end{array}$ & $\begin{array}{c}\text { Fruits } \\
\text { per bunch }\end{array}$ \\
\hline 1964 & Days & Pounds & Grams & Ratio & Number & Number \\
\hline November & 156 & 58.1 & 175.7 & 1.37 & 9 & 153 \\
\hline $\begin{array}{c}\text { December } \\
1965\end{array}$ & 145 & 55.8 & 167.2 & 1.25 & 8 & 150 \\
\hline January & 136 & 50.6 & 151.0 & 1.21 & 8 & 123 \\
\hline February & 148 & 56.1 & 195.2 & 1.56 & 8 & 135 \\
\hline March & 149 & 55.9 & 182.7 & 1.50 & 8 & 139 \\
\hline April & 142 & 59.2 & 212.6 & 1.62 & 8 & 132 \\
\hline May & 126 & 52.8 & 193.5 & 1.49 & 8 & 129 \\
\hline June & 124 & 48.5 & 185.1 & 1.46 & 8 & 121 \\
\hline July & 121 & 52.8 & 172.6 & 1.41 & 8 & 137 \\
\hline August & 125 & 53.1 & 173.7 & 1.36 & 8 & 142 \\
\hline September & 130 & 50.5 & 158.8 & 1.36 & 8 & 145 \\
\hline October & 127 & 49.1 & 141.2 & 1.18 & 8 & 153 \\
\hline November & 145 & 43.9 & 151.2 & 1.25 & 9 & 159 \\
\hline December & 154 & 55.2 & 156.8 & 1.34 & 9 & 170 \\
\hline
\end{tabular}

maximum by the flowering of April (see curve $B$ of fig. 11) to decrease again to reach a minimum by November 1965 . The weight of the fingers thus varies with the month of flowering.

The number of fruit per bunch also varied with the month of flowering decreasing from about 153 fingers per bunch from the flowering of November 1964 to reach a minimum value of 121 fingers for the flowering of June, increasing steadily again to 170 fingers for the flowering of December 1965.

Although the average weight of the bunches remained fairly constant throughout the year, the weight of the individual bunches varied within wide range within each group harvested by month of flowering. Table 4 shows the percentage of bunches harvested of several weight ranges by month of flowering. When the bunches produced from all plots are grouped 

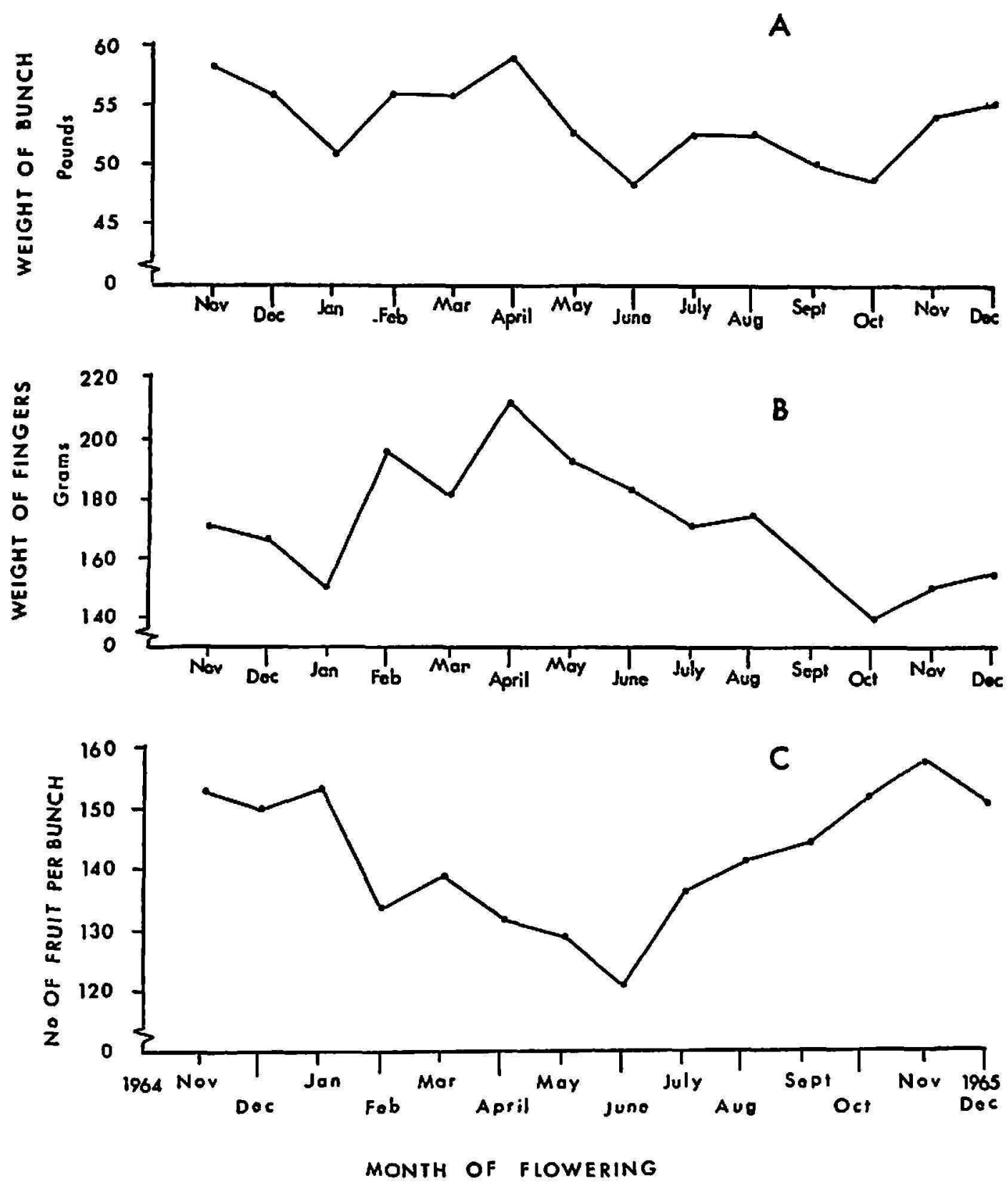

Fia. 11.-Variation of the weights of the bunch, of the fruit, and the number of fruits per bunch with the month of flowering.

according to their weights, the distribution shown in figure 12 is obtained. Of a total of 795 bunches, 81 percent weighed from 40 to 65 pounds.

\section{THE EFFECT OF THE TIME OF SHOOTING ON THE RIPENING CHARACTERISTICS}

To study the ripening characteristics of the fruit, the ripening methods described under Experimental Procedures were followed for all lots. In general, the fruit was removed from the ripening rooms 5 days after being put in. The ripening characteristics were determined in terms of the percentage of fingers per bunch which ripened to a color of $4-5$, and by the brilliance 
TABLE 4.-Weight distribution of bunches produced by plants flowering within a calendar month

\begin{tabular}{|c|c|c|c|c|c|c|c|c|c|c|c|c|}
\hline \multirow{2}{*}{$\begin{array}{l}\text { Month of } \\
\text { inflorescence }\end{array}$} & \multicolumn{12}{|c|}{ Percentage of bunches harvested of weight range in pounds indicated } \\
\hline & 30.0 & $\begin{array}{r}30.0- \\
34.9\end{array}$ & $\left|\begin{array}{r}35.0- \\
39.9\end{array}\right|$ & $\begin{array}{l}40.0- \\
44.9\end{array}$ & $\begin{array}{l}45.0- \\
49.9\end{array}$ & $\begin{array}{l}50.0- \\
54.9\end{array}$ & $\begin{array}{l}55.0- \\
59.9\end{array}$ & $\begin{array}{l}60.0- \\
64.9\end{array}$ & 0.9 & $\begin{array}{l}70.0- \\
74.9\end{array}$ & $\begin{array}{l}75.0- \\
79.9\end{array}$ & 80.0 \\
\hline & & & & & & & & & & & & \\
\hline ov & - & - & - & 5.3 & 15.8 & 31.6 & 10.5 & 5.3 & 21.0 & 10.5 & - & - \\
\hline $\begin{array}{c}\text { ecember } \\
1965\end{array}$ & - & 2.9 & 4.4 & 13.2 & 7.4 & 17.7 & 22.0 & 22.0 & 7.4 & 1.5 & 1.5 & - \\
\hline January & -1 & - & 8.3 & 8.3 & 33.3 & 30.6 & 2.8 & 11.1 & 2.8 & 2.8 & 一 & - \\
\hline February & - & 8.3 & 8.3 & - & 25.0 & 一 & 25.0 & 16.7 & 16.7 & - & - & 一 \\
\hline March & -1 & - & 5.4 & 13.5 & 16.2 & 18.9 & 16.2 & 8.1 & 13.5 & 5.4 & 2.8 & - \\
\hline Anril & - & - & - & 10.5 & 10.5 & 10.5 & 21.0 & 21.0 & 21.0 & 5.5 & - & - \\
\hline & -1 & - & 5.1 & 10.3 & 20.5 & 25.6 & 23.1 & 7.7 & 5.1 & 2.6 & - & - \\
\hline & - & 1.9 & 5.7 & 24.5 & 28.3 & 26.4 & 9.4 & - & - & 1.9 & 1.9 & - \\
\hline & -1 & 3.9 & 5.9 & 14.7 & 22.6 & 15.7 & 9.8 & 13.7 & 7.8 & 5.9 & - & - \\
\hline us & 1.3 & 3.7 & 5.0 & 11.4 & 21.5 & 15.2 & 16.5 & 16.5 & 7.6 & 1.3 & - & - \\
\hline ber & - & 2.8 & 8.3 & 15.3 & 20.8 & 22.2 & 16.7 & 6.9 & 4.2 & 2.8 & - & - \\
\hline & 1.0 & 2.9 & 7.6 & 21.7 & 20.9 & 19.1 & 13.3 & 8.6 & 1.0 & 2.9 & - & 1.0 \\
\hline & - & - & 4.5 & 8.1 & 12.6 & 22.5 & 27.0 & 14.4 & 4.5 & 5.4 & 0.9 & - \\
\hline cember & - & - & 5.9 & 5.9 & - & 17.7 & 41.3 & 29.4 & - & - & - & - \\
\hline
\end{tabular}

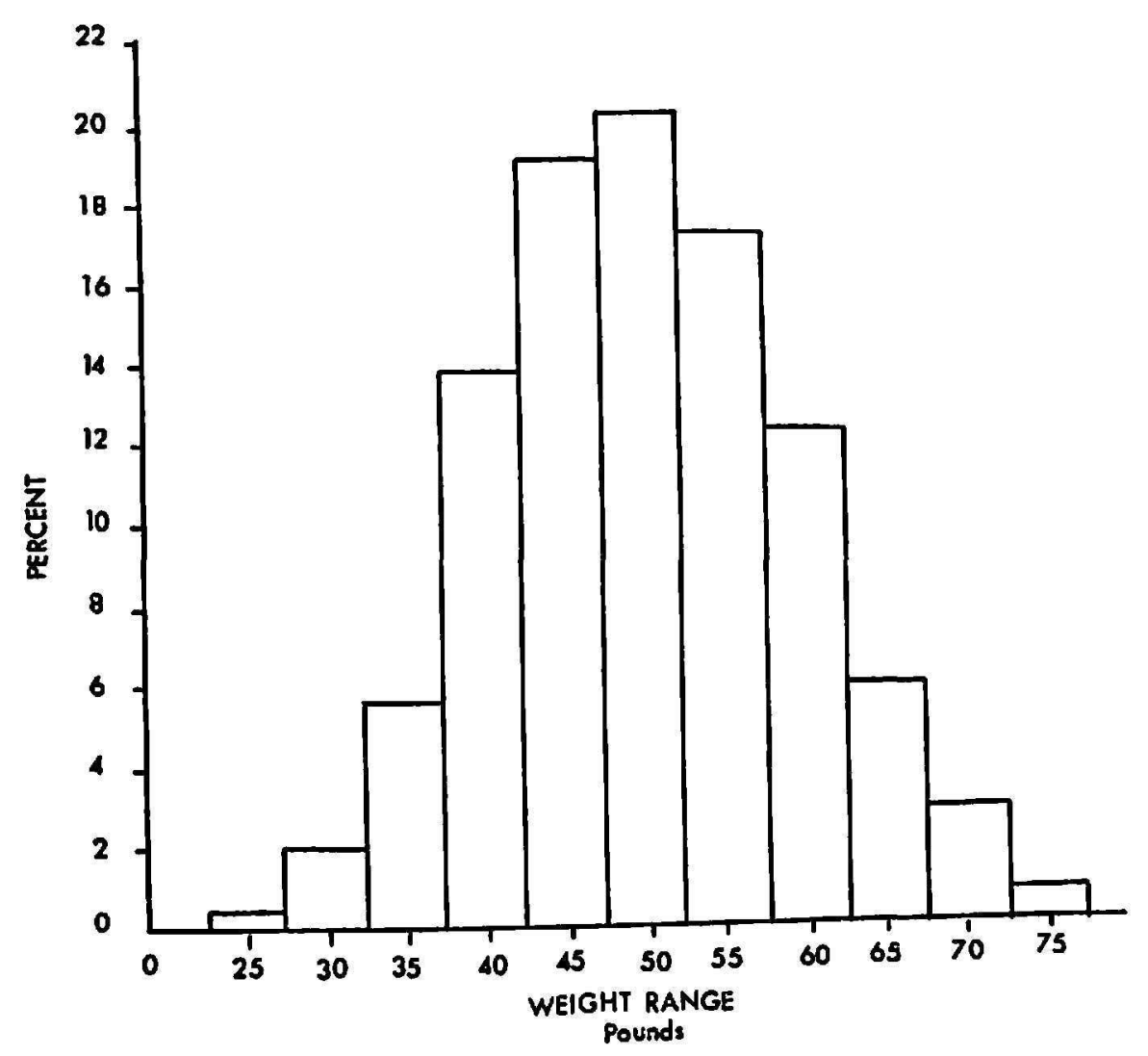

Fra. 12.-Distribution by weight of bunches produced from the 12 plots. 
of the yellow color. In the following tabulation the percentage of bunches ripening completely are grouped by month of flowering:

$\begin{array}{lc}\text { Monsh of fosoering } & \begin{array}{c}\text { Percenlage bunches ripening } \\ \text { uniformly }\end{array} \\ \text { November } & 100.0 \\ \text { December } & 87.2 \\ \text { January } & 63.1 \\ \text { February } & 100.0 \\ \text { March } & 100.0 \\ \text { April } & 100.0 \\ \text { May } & 100.0 \\ \text { June } & 98.0 \\ \text { July } & 85.7 \\ \text { August } & 100.0 \\ \text { September } & 100.0 \\ \text { October } & 98.1 \\ \text { November } & 100.0\end{array}$

With the exception of 3 months, December, January, and July, the bunches ripened fairly uniformly. The low percentage of bunches ripening corresponding to the flowering of December and January may be due to the fact that these bunches developed during periods of cold weather. Simmonds (1) reports that Lacatan bananas from Jamaica, and Dwarf Cavendish from Brazil, harvested during the winter months, ripened less satisfactorily than fruit harvested during the summer months. We observed that, in general, fruit cut during the winter months ripened less satisfactorily than during the summer months. During the winter months the fruit ripened to a dull yellow-color, sometimes lacking the yellow tip at color 4-5, while fruit cut during the summer ripened to a more attractive yellow color with a green tip.

\section{GENERAL CHARACTERISTICS OF THE FRUIT HARVESTED}

In the course of this study, bananas were harvested from April 1965 to June 1966. It is worthwhile to consider the general characteristics of the fruit produced from all 12 plots disregarding the effects of time of planting and flowering.

With a density of 400 plants per cuerda, with the bananas growing under full sunlight, controlling the leaf spot disease by spraying regularly with Orchard Oil, the average weight of the bunches harvested was 52.03 pounds.

In table 5 the weight of the hands and the number of fruits per hand are given for bunches grouped according to their weights. In general, the weight of the first and second hands was about twice that of the last hand. The first and second hands had each about twice the number of fruits as the last hand. In general, the bunches were irregular in shape mostly due to the variation in the number of fingers per hand from top to bottom. 
TABLE 5.-Weight of hands in pounds $(A)$ and number of fruits per hand $(B)$ in bunches harvested grouped by their weights in pounds

\begin{tabular}{|c|c|c|c|c|c|c|c|c|c|c|c|c|c|c|c|c|c|c|c|c|}
\hline \multirow{2}{*}{ Hand No. } & \multicolumn{2}{|c|}{$\begin{array}{c}30.0- \\
34.9\end{array}$} & \multicolumn{2}{|c|}{$\begin{array}{l}35.0- \\
39.9\end{array}$} & \multicolumn{2}{|c|}{$\begin{array}{c}40.0- \\
44.9\end{array}$} & \multicolumn{2}{|c|}{$\begin{array}{l}45.0- \\
49.9\end{array}$} & \multicolumn{2}{|c|}{$\begin{array}{c}50.0- \\
54.9\end{array}$} & \multicolumn{2}{|c|}{$55.0-$} & \multicolumn{2}{|c|}{$60.0-9$} & \multicolumn{2}{|c|}{$65.0-69.9$} & \multicolumn{2}{|c|}{ 70-74.9 } & \multicolumn{2}{|c|}{ 75.0-79.9 } \\
\hline & A & $B$ & A & B & A & B & $A$ & B & A & B & $A$ & B & A & $B$ & $A$ & B & A & B & A & $B$ \\
\hline 1 & 5.3 & 24 & 5.1 & 24 & 9.0 & 25 & 7.5 & $?$ & 7 & & 0.2 & 16 & 8.7 & 22 & 2.23 & & 10.8 & 21 | & 8.7 & 1 \\
\hline 2 & 5.8 & 23 & 6.8 & 22 & 6.5 & 19 & 6.5 & 23 & 9.7 & 26 & 9.5 & 22 & 8.9 & 21 & 8.4 & 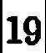 & 10.1 & 21 & 10.8 & \\
\hline 3 & 5.7 & 20 & 5.9 & 19 & 5.8 & 18 & 8.3 & 23 & 6.5 & 17 & 7.6 & 19 & 7.8 & 19 & 10.9 & 22 & 9.9 & 21 & 10.0 & 20 \\
\hline 4 & 4.2 & 14 & 4.8 & 16 & 5.2 & 16 & 6.2 & 17 & 5.8 & 15 & 6.5 & 17 & 6.5 & 17 & 8.5 & 18 & 7.9 & 18 & 8.9 & 19 \\
\hline 5 & 4.1 & 14 & 4.4 & 15 & 4.6 & 15 & 5.5 & 15 & 5.7 & 16 & 5.9 & 17 & 6.2 & 17 & 7.6 & 17 & 7.4 & 17 & 8.0 & 18 \\
\hline 6 & 3.8 & 14 & 4.0 & 15 & 4.3 & 15 & 4.9 & 15 & 4.9 & 15 & 5.2 & 16 & 5.2 & 15 & 7.1 & 17 & 6.8 & 16 & 7.4 & 17 \\
\hline 7 & 3.5 & 14 & 3.6 & 14 & 3.9 & 14 & 4.5 & 14 & 4.6 & 15 & 4.9 & 15 & 4.8 & 15 & 6.3 & 16 & 5.9 & 15 & 6.6 & 16 \\
\hline 8 & 3.1 & 13 & 3.0 & 13 & 2.7 & 12 & 4.1 & 14 & 4.2 & 15 & 4.5 & 15 & 3.9 & 14 & 5.9 & 15 & 5.6 & 15 & & 15 \\
\hline 9 & 2.3 & 12 & 2.2 & 11 & - & - & 3.7 & 13 & 2.6 & 11 & 2.6 & 10 & 2.8 & 10 & 5.6 & 15 & 4.8 & 14 & 5.5 & 16 \\
\hline 10 & & & & & & & 2.9 & 12 & & & & & 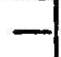 & - & 3.8 & 12 & 3.4 & 11 & 2.4 & 9 \\
\hline
\end{tabular}

TABLE 6.-Characteristics of the fruil harvested from April 1965 to June 1966

\begin{tabular}{|c|c|c|c|c|c|c|}
\hline Month harvested & Age & $\begin{array}{c}\text { Average } \\
\text { weight of } \\
\text { bunch }\end{array}$ & $\begin{array}{c}\text { Average } \\
\text { weight of } \\
\text { Gngers }\end{array}$ & Pulp:peel & $\begin{array}{c}\text { Hands per } \\
\text { bunch }\end{array}$ & $\begin{array}{c}\text { Fruits per } \\
\text { bunch }\end{array}$ \\
\hline & Days & Pounds & Grams & Ralio & Number & Number \\
\hline \multicolumn{7}{|l|}{1965} \\
\hline April & 126 & 46.0 & 138.7 & 1.08 & 9 & 155 \\
\hline May & 144 & 55.7 & 163.9 & 1.25 & 8 & 154 \\
\hline June & 153 & 57.8 & 175.4 & 1.37 & 8 & 144 \\
\hline August & 149 & 56.6 & 189.1 & 1.54 & 8 & 137 \\
\hline September & 131 & 54.3 & 195.5 & 1.53 & 8 & 131 \\
\hline October & 121 & 46.6 & 181.9 & 1.43 & 8 & 120 \\
\hline November & 120 & 52.3 & 172.1 & 1.40 & 8 & 136 \\
\hline $\begin{array}{c}\text { December } \\
1966\end{array}$ & 123 & 53.7 & 170.5 & 1.37 & 8 & 140 \\
\hline January & 130 & 50.5 & 162.9 & 1.38 & 8 & 145 \\
\hline February & 124 & 48.4 & 139.5 & 1.17 & 8 & 151 \\
\hline March & 138 & 52.1 & 143.7 & 1.16 & 8 & 162 \\
\hline April & 149 & 56.7 & 158.1 & 1.32 & 9 & 160 \\
\hline May & 161 & 60.5 & 166.1 & 1.32 & 9 & 157 \\
\hline June & 159 & 54.5 & 159.6 & 1.44 & 9 & 152 \\
\hline
\end{tabular}

In table 6 the characteristics of the fruit harvested each month from April 1965 to April 1966 are given. All bunches harvested were of marketable quality. The average number of hands ranged from 8 to 9 , with a few having 7 and 10 hands.

In general, ripening characteristic was poor. When ripened at $68^{\circ} \mathrm{F}$. with ethylene application, as described under Experimental Procedures, the 
fruit ripened to a dull yellowish-green color. When fully ripe, the color was dull yellow, lacking brilliance. From the standpoint of flavor, the fruit was acceptable, but was considered to be of inferior quality to the fruit harvested at the Fortuna Substation on the South Coast of Puerto Rico. The keeping quality of the ripe fruit was poor, while processing characteristics were good. Purees prepared from these bananas were found to have a nice yellow color and good flavor.

\section{GENERAL CONSIDERATIONS}

The results obtained from this work point to the need of further research on bananas growing on the Humid Mountainous Region of Puerto Rico. If bananas are going to be produced commercially in well organized plantations, further work must be done to determine the best time for planting. This work indicates that when planted monthly from December to November the following year, two flowering cycles resulted, with a low percentage of plants flowering from November to May and the higher percentage of plants flowering from May to January. The length of the period of flowering is related to the time of flowering and to prevailing weather conditions.

The time of flowering had a direct effect on the development of the bunch. Bunches from the flowering of November to March were slow to develop and had to be harvested at a fairly advanced age to be of marketable quality. From March to August, the development of the bunch was more rapid and the bunches could be harvested at an earlier age. From the flowering of August to November, the development of the bunch was slow again, and had to be harvested at a more advanced age. This means that from the point of view of production, it would be desirable to establish plantations at such a time that the higher percentage of the plants will bloom uniformly in a short time. However, if this is done, the plantation will be producing fruit during the cold months when the development of the bunch is slow and ripening characteristics are poor. Consequently, further research must be undertaken to study the interrelation of all these factors so that proper planting schemes can be established.

When weather conditions are considered, the climate at the Adjuntas Substation was unfavorable to the production of bananas, mainly due to the minimum low temperatures prevailing throughout the year. In contrast, in a previous work by the authors at the Fortuna Substation on the Southern Coast of Puerto Rico, excellent fruit was obtained the year around.

Between Fortuna and Adjuntas there is a difference in elevation of 1,800 feet and, therefore, in between these two extremes there is a large area suitable for banana cultivation. Further research is needed to determine the effect of different elevations on banana production in order to select the most suitable zones to develop this industry. 
In this work the planting material for the experimental plots was selected at random from the farm at Adjuntas, and the possibility is that several clones were included which may account for some of the wide variations in quality and other characteristics observed cannot be discarded. However, even with this material, which is similar to that available to farmers, very high yields were obtained with a quality of the fruit suitable for the fresh local market, or for processing by just using proper agronomical practices and harvesting techniques.

As indicated in the Experimental Procedures, the leaf spot disease was controlled by spraying the plants with Orchard Spray Oil every 15 days. This practice proved to be effective in controlling the disease, only two plots being affected by Sigatoka. Even in these two plots, at the time of harvesting the average number of leaves ranged from 7 to 9 and the weights of the bunches harvested were similar to the weights of those harvested from healthy plants.

\section{SUMMARY}

Montecristo bananas were planted monthly under sunlight at the Adjuntas Substation in the Mountainous region of Puerto Rico. The time of planting was found to affect the flowering span, which ranged from a minimum of 107 days to a maximum of 200 days. The plots with the longest flowering span started to bloom during the month of February coinciding with a period of low minimum temperatures and scant rainfall. The flowering characteristics of the plots did not follow any definite pattern, some plots showing a skewed-type distribution with the highest percentages of the plants flowering near the beginning or the end of the flowering period. The flowering pattern of the 12 plots combined exhibits two definite periods of low and high percentage of plants flowering, with the highest percentage of plants flowering during the months of June to November.

The development of the bunch was related to the time at which shooting occurred. The time required for the bunches to reach a definite stage of development decreased from the flowering of November to the flowering of July, to increase again from August to November. The time of flowering had very little effect on yields, the weight of the bunches harvested ranging from 48.0 to 58.0 pounds. The weight of the fingers varied with the time of flowering. The weight of the fingers increased from the flowering of November to the flowering of April, decreasing again to reach a minimum by November. The number of fruits per bunch also varied with the time of flowering, decreasing from November to June to increase again from June to November.

Ripening characteristics were poor, particularly during the winter months, when the bananas ripened to a dull yellow color lacking brilliance. From the standpoint of flavor, the quality of the fruit was acceptable. 
Processing characteristics were good. Purees prepared from these fruits had a nice color and good flavor.

\section{RESUMEN}

Se establecieron siembras mensuales de guineo de la variedad Montecristo, sin sombra, en la Subestación de Adjuntas ubicada en la Región Montañosa de Puerto Rico.

La época de la siembra afectó la duración de la florecida en cada siembra. El periodo de la florecida fluctuó desde un mínimo de 107 días a un máximo de 200 días. Las siembras cuyos periodos de florecida fueron más prolongadas, comenzaron a florecer durante el mes de febrero, coincidiendo esto con periodos de temperaturas muy bajas y de muy poca lluvia.

Las florecidas de las 12 siembras no siguieron un patrón definido. En algunas siembras, un porcentaje mayor de plantas florecieron al principio del periodo de la florecida, mientras que en otras el mayor número de plantas floreció al final. Cuando se consideraron las 12 siembras en conjunto, se observaron dos periodos de florecida definidos; el porcentaje mayor de las plantas floreció durante los meses de junio a noviembre.

La época de la florecida afectó el desarrollo del racimo. El tiempo requerido para que los racimos llegaran a un estado de desarrollo determinado disminuyó desde la florecida de noviembre hasta la de julio, aumentando de nuevo hasta la florecida del próximo noviembre.

La época de la florecida tuvo poco efecto sobre el peso de los racimos. El peso promedio de los racimos cosechados y agrupados según el mes de la florecida fluctuó entre 48 y 58 libras. La época de la florecida afectó el peso de la fruta y el número de frutas por racimo. El peso promedio de la fruta fue en aumento desde la florecida de noviembre hasta la de julio, y luego disminuyó hasta la florecida del próximo noviembre. El número de frutas por racimo varió según la época de la florecida, disminuyendo desde la florecida de noviembre hasta la de junio, para luego aumentar de junio a diciembre.

La fruta que se cosechó, particularmente durante los meses más fríos, no maduró satisfactoriamente. El color de la fruta madura fue amarillo verdoso o amarillo obscuro, sin brillantez. El sabor de la fruta fue aceptable. De esta fruta también fue posible elaborar purés de buena calidad.

\section{LITERATURE CITED}

1. Simmonds, N. W., Bananas, Longmans, Green, \& Co., Ltd., London, England, 129-144, 1960.

2. Sánchez Nieva, F., Colom-Covas, G., Hernández, I., Bueso de Viñas, C., and Guadalupe, R., Studies on the Production of the Montecristo banana grown on the South Coast of Puerto Rico, J. Agr. Univ. P.R., 68 (4): 1969. 
3. Champion, J., Le Bananier, G. P. Maisonneuve and Larose, Paris, France, 171 pp., 1963.

4. Wardlaw, C. W., Leonard, E. R., and Barnell, H. R., Metabolic and storage investigations on the banana, Low Temp. Res. Sta., Imp. College of Trop. Agr., Trinidad, Memoir 11: 3-8, 1939.

5. Banana Ripening Manual, Fruit Dispatch Co., Boston, Mass., 32 pp., 1961. 